Historic, Archive Document

Do not assume content reflects current scientific knowledge, policies, or practices. 



\section{LAKE RIPLEY GLADIOLI}

ie

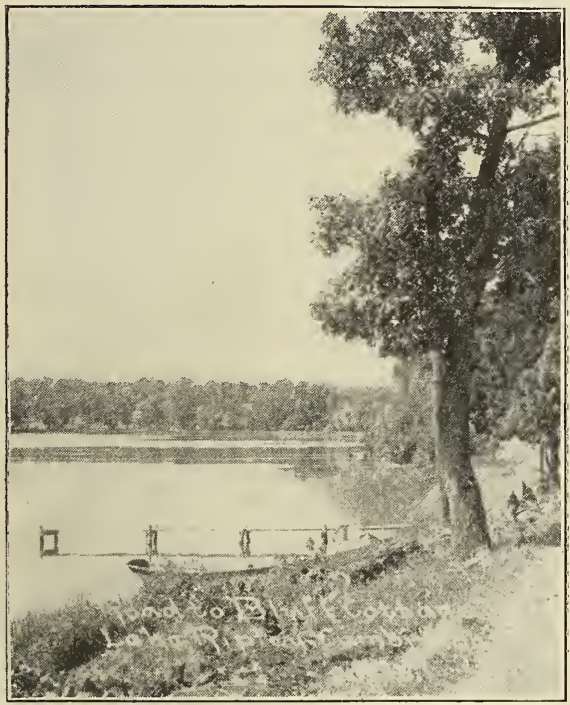

7 HIS IS THE SEVENTH year I am growing and breeding gladioli. Here in the lake region of Southern Wisconsin we grow thesebeautiful flowers to perfection. Every summer I try out hundreds of varieties from the best hybridizers of this country and Europe. Those I offer in this list are some of the best. The modern gladiolus is a wonder. Long spikes of magnificent blossoms that often rneasure five and six inches in diameter. And such a range of gorgeous colors. They are the most stately decorative plant for the garden and there is no better cut flower for the home. If spikes are cut and placed in water when first bud opens, they will last a week or ten days.

Any soil that will grow potatoes will grow gladioli. Plant bulbs in well prepared soil about five inches deep and four inches apart in rows or beds. Make successive plantings from April till last of June. They bloom about three months after planting. Bulbs should be dug before the ground freezes and stored in a dry frost-proof place.

All bulbs sent prepaid at prices quoted. Remit tances must accompany all orders. Send your order early for Lake Ripley Quality Bulbs and you will get select, strong, healthy, bulbs that will yield large blossoms.

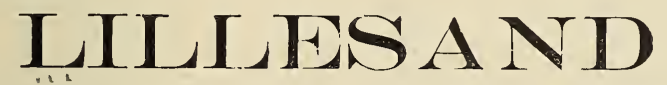




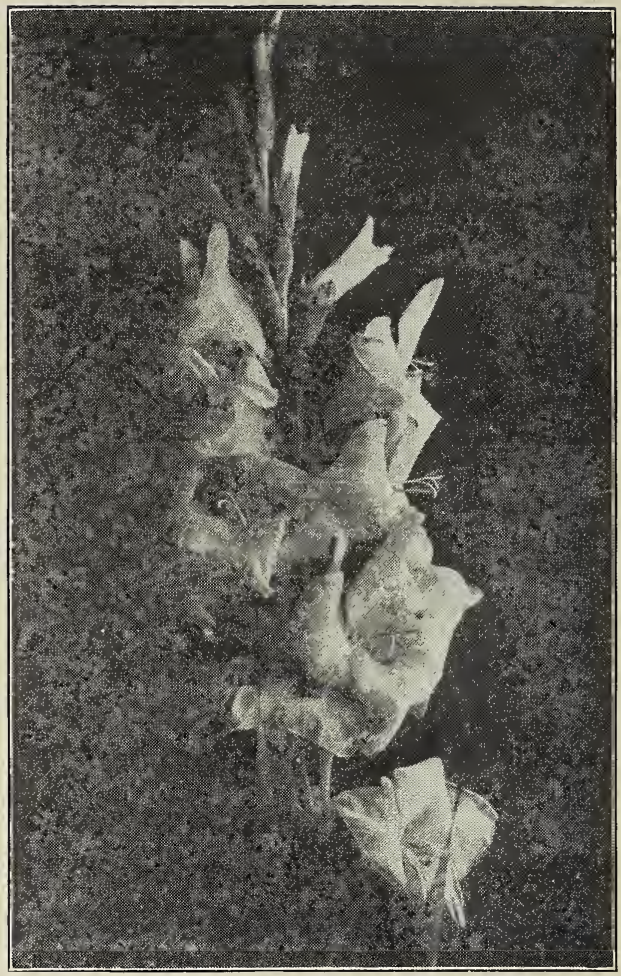

Niagara

NIAGARA (Banning) A splendid new variety of same type as "America". A delightful cream color -tinted canary and throat penciled with carmine. A strong spike with wide flowers over four inches across. Exceptionally fine. 12c each 3 for $30 \mathrm{c}$, $\$ 1.20$ per dozen.

BURRELL (Woodruff) A splendid dark red flower with beautiful butterfly marking in throat. $10 \mathrm{c}$ each; 3 for 25c; 90 c per dozen.

GOLDEN KING (Black) Rich golden yellows with red blotch in throat. A splendid yellow-one of the finest to date. $15 \mathrm{c}$ each, 3 for $40 \mathrm{c}, \$ 1.60$ per doz.

IDA VAN (Kunderd) This is a new large lily shaped flower of bright red with a blotch of darker red on the lower petals. Six open at once. Much admired on account of its imposing appearance. $15 \mathrm{c}$ each, 2 for $25 c, \$ 1.50$ per dozen. 


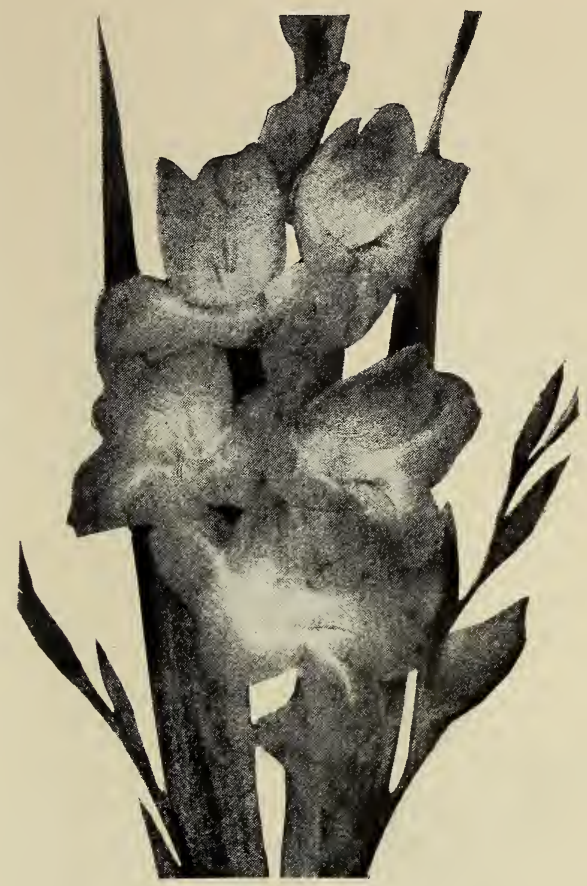

Halley

HALLEY (De Ruyter) Another new variety of much merit-from Holland. The color is a delicate salmon pink with a slight roseate tinge. The lower petals bear a creamy blotch with a stripe of bright red thru the center. $10 \mathrm{c}$ each, 3 for $25 \mathrm{c} 90 \mathrm{c}$ doz.

INDEPENDENCE (Woodruff) A rich rosy red-always brilliant and pleasing. Very prolific-that's why it is cheap. $5 \mathrm{c}$ each, 3 for $12 \mathrm{c}, 40 \mathrm{c}$ doz, $\$ 3.00$ per 100.

PANAMA (Banning) A large bold flower like "America" only a much brighter pink. One of the finest yet produced. Have been awarded many prizes. 15c each, $\$ 1.80$ per dozen.

KATIE NANCE. A beautiful large red maroon blossom with a creamy yellow blotch on two lower petals. Sturdy spike of 12 buds with four to five open at once. Wide flowers often $4 \frac{1}{2}$ inches across, 10c each, 3 for $25 \mathrm{c}, 90 \mathrm{c}$ per dozen.

MEPHISTOPHELES (Lemoine) Bright crimson splashed with dark crimson and yellow. Effective for the garden. $8 \mathrm{c}$ each, 3 for $20 \mathrm{c}, 75 \mathrm{c}$ dozen. 


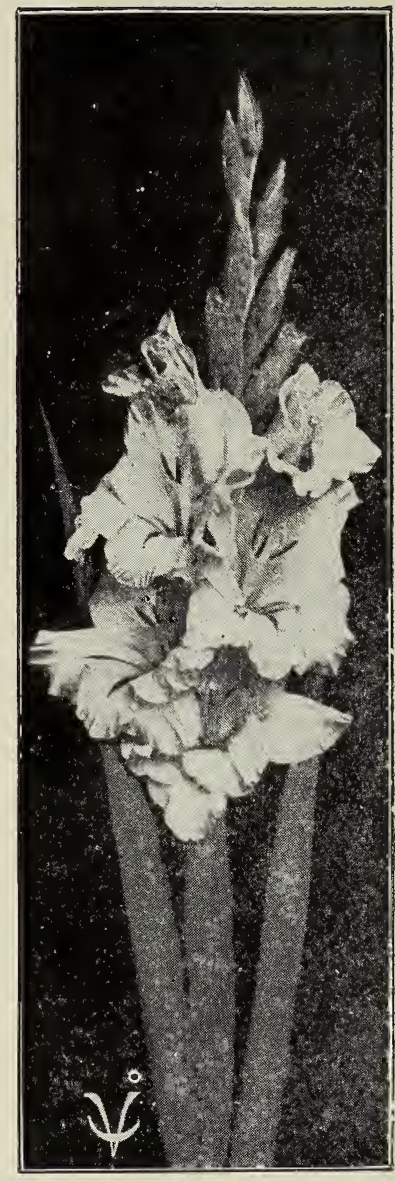

Glory
GLORY (Kunderd) The new ruffled gladiolus, delicate cream pink with neat crimson stripe in the center of each lower petal. A rooust plant producing large well opened flowers. 10c each, 3 for 25 c $\$ 1$ per dozen.

DAWN (Tracy) A beautiful shell pirik with long graceful spike and many flowers open at one time. Extra fine 15c each; 3 for $40 \mathrm{c}$; $\$ 1.50$ per doz.

EMPRESS OF INDIA (Velthwys) A new one from Holland. Rich dark red with a purnlish tinge. Probably the darkest variety to late. Rare and beautiful. $12 \mathrm{c}$ each, 3 for $35 \mathrm{c}, \$ 1.25$ per dozen.

E U R O A (Pfitzer) Snowy white without a trace of color. Probably the finest pure white yet offered. 25c each. 3 for $70 \mathrm{c}, \$ 2.50$ per doz.

EVALINE (Groff) Violet underlaced terra cotta-or a smokv violet-a unique flower. 8c each, 3 for $20 \mathrm{c}, 75 \mathrm{c}$ doz.

LILLY LEHMAN A lily shaped white from Holland. Mottled in throat, slender, graceful spike, $10 \mathrm{c}$ each, 3 for $25 \mathrm{c}, \$ 1.00$ per dczen.

MARGARET (Crawford) Brilliant carmine with a large white blotch on lower petals. Large plant and flower. Very desirable. $15 \mathrm{c}$ each, 2 for $25 \mathrm{c}$, $\$ 1.40$ per dozen.

BALTIMORE (Groff) A spleridid wide open flower. A beautiful salmon with large red spot in throat. Very showy singly or in bouquets. $10 \mathrm{c}$ each, 3 for $25 \mathrm{c}$ 90c per dozen. 


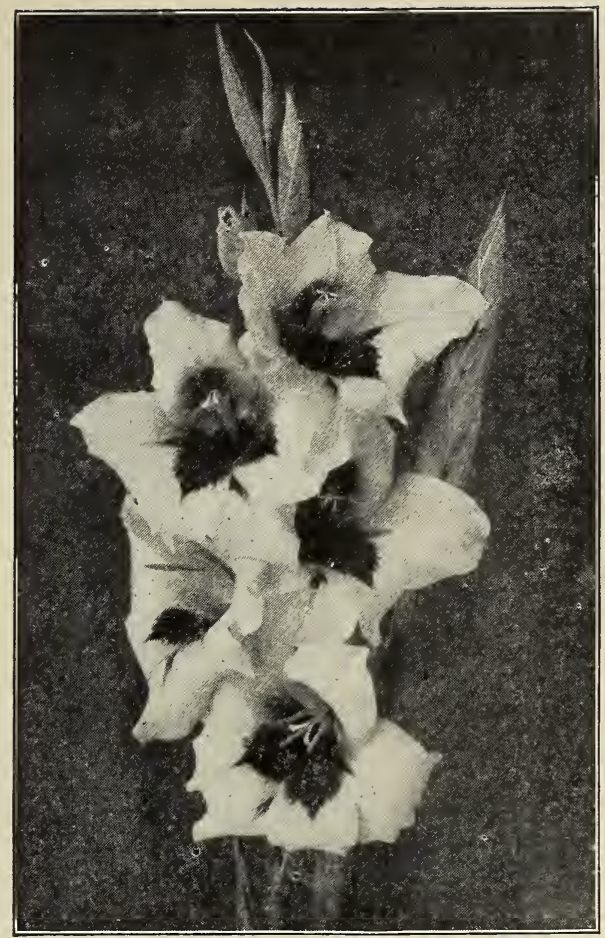

Jane Dieulafoy

JANE DIEULAFOY (Lemoine) Large bold flowers of creamy white with carmine blotch on lower petals. An excellent bedding variety. 10c each, 3 for $25 \mathrm{c}, 90 \mathrm{c}$ per dozen.

MRS. FRANCIS KING (Coblentz) A vary large flame nink. kordering on red. Long spike of 18 huds with 6 to 8 open at once. $5 \mathrm{c}$ each, 3 for $12 \mathrm{c}$, 35 c per dozen.

MRS. FRANK PENDLETON, JR., (Kunderd) A very large well expanded flower of lovely flushed salmon pink with a brilliant carmine or deep blood red blotsh in throat, presenting a vivid contrast Awarded many prizes and decidedly one of the most reautiful gladioii to date. $25 \mathrm{c}$ each, 3 for $65 \mathrm{c}$, $\$ 2.50$ per dozen.

MYRTLE (Kunderd) A most exquisite shell pink lightly penciled with rose with creamy white throat. Flowers of good size and graceful form. Four to six open at once. Blooms early, 25e each, 3 for 70 c, $\$ 2.75$ per dozen. 


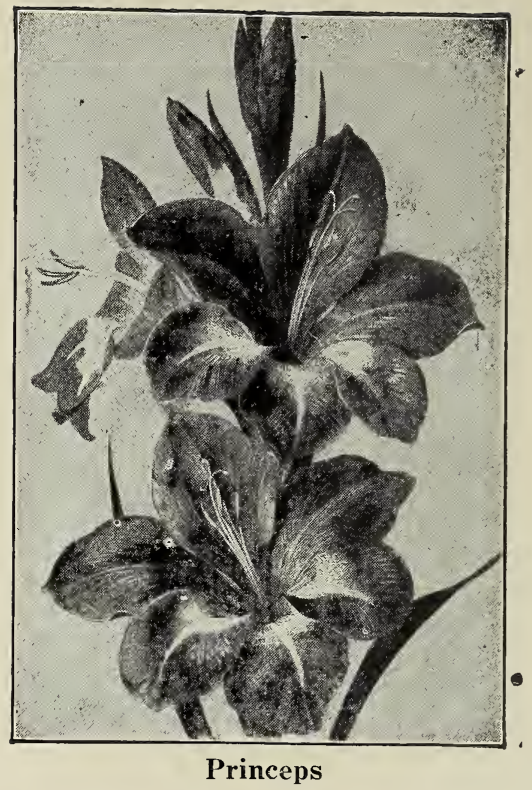

PRINCEPS (Van Fleet) An immense flower of bright scarlet with broad white blotches across the lower petals. Few blooms open at once. 8c each, 3 for 20c, $75 \mathrm{c}$ per dozen.

PAULHAM Dark violet with paler shade in center. A purplish red blotch edged with creamy white on lower petals. 2c each, 3 for 35c, $\$ 1.35$ doz.

PEACE (Grofi) A tall thrifty plant with beautiful large white flowers-faint streaks of pink in throat. One of the good late sorts. 10c each, 3 for 25c, $\$ 1$ per dozen.

PRESIDENT TAFT Delicate salmon pink shaded darker at edges red blotch in throat and a light line thru each petal. $8 \mathrm{c}$ each, 3 for $20 \mathrm{c}, 75 \mathrm{c}$ per dozen.

TACONIC (Cowee) Bright lively pink, shading to blush in throat. Lower petals marked bright crimson, running into a thin stripe of white. Showy and beautiful. $8 \mathrm{c}$ each, 3 for $20 \mathrm{c}, 75 \mathrm{c}$ per dozen.

WM. MASON (Crawford) A fine red of large size and good appearance. $8 \mathrm{c}$ each, 3 for $20 \mathrm{c}, 75 \mathrm{c}$ per dozen.

J. S. HENDRICKSEN (Childs) A large blossom with irregular mottling of white and bright pink, very beautiful. 10c each, 3 for $25 \mathrm{c}, 90 \mathrm{c}$ doz.

KLONDIKE (Christy) Clear primrose yellow with a blotch of vivid crimson. A vigorous plant of 15 buds with 4 to 5 open at once. Early bloomer. 6c each, 3 for $5 \mathrm{c}, 50 \mathrm{c}$ doz., $\$ 4.00$ per 100 . 


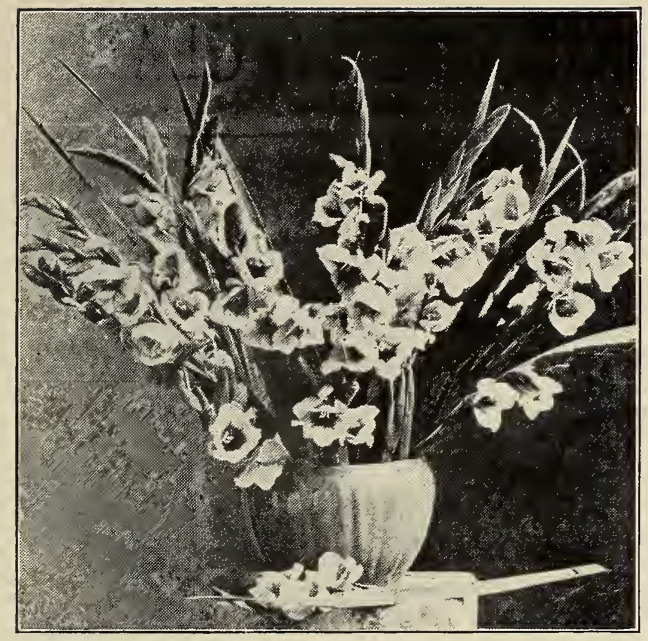

Klondike

RIPLEY MIXED This superb mixture is corposed of splendid named varieties and also include some large flowering seedlings. I take special pairs to have a large range of colors. This is my "extr... quality" mixture and I believe it will suit the mos: critical buyer. 6c each, 60c doz, $\$ 4.00$ per 100 .

MONONA MIXED This is my florists white ar: light mixture. It is made up of whites, light pinks yellows and those light shades that are most cui. able for florists use as well as home decoratio... $4 \mathrm{c}$ each, 40c doz., $\$ 3.00$ per 100 .

MARVEL MIXED This is an extra standard mixture composed of light, bright and darker colors-well balanced and prepared for those who want qua ity bulbs at a low price. It ought to be planted i large quantities at these prices. 3c each, 30c pcr. dozen, $\$ 2.00$ per 100 .

SECTION I Reds, scarlets and crimsons with beavtiful markings, $4 \mathrm{c}$ each, $40 \mathrm{c}$ per dozen, $\$ 2.50$ per $10 \mathrm{~J}$

SECTION II Whites, light pinks and yellows i many combinations. $5 \mathrm{c}$ each $50 \mathrm{c}$ per dozen, $\$ 3$. c $^{\circ}$ per 100.

SECTION III Rare blues in clematis lilac an ? heliotrope shades. $\quad 6 \mathrm{c}$ each, $60 \mathrm{c}$ doz., $\$ 4.50$ per 100. 


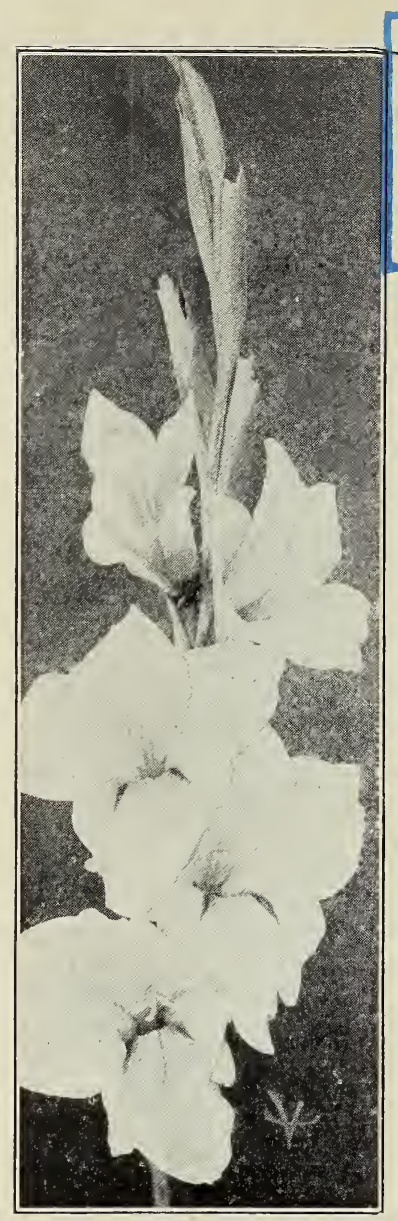

Chicago White
AMERICA (Banning) The most popular gladiolus in/ Anneriêa 17today. Large beautfful tssoft tayender shell pink. $5 \mathrm{c}$ each; 3 for $12 \mathrm{c}$; $35 \mathrm{c}$. Adozivi2.50. per. 100.

ATTRACTION (Childs) Deep rich crimson with a conspicuous large white throat. $7 \mathrm{c}$ each. 3 for $18 \mathrm{c}$; 60c doz. $\$ 4.00$ per 100 .

CARDINAL KING (Kunderd) Very brilliant solid cardinal scarlet. Flowers ind spike of good size. Fine. $12 \mathrm{c}$ each; 3 for $35 \mathrm{c} ; \$ 1.35$ per doz.

CHICAGO WHITE (Kunderd) New White not large but real early. Faint lavender sireaks on lower petals. Try a few for early flowers.

$8 \mathrm{c}$ each; 3 for $20 \mathrm{c}$; $75 \mathrm{c}$ doz; $\$ 5.50$ per 100 .

C R A C K E R JACK (Cowee) Rich velvety dark red flowers - throat spotted with yellow and dark maroon. Slender spike of 12 buds with 4 open at once. $8 \mathrm{c}$ each 3 for $20 \mathrm{c} ; 75 \mathrm{c}$ doz.; $\$ 6$ per 100.

AUGUSTA (Hallock) The well known commercial white--often tinted lavender. Anthers blue. Strong spike often branched. 5c each; 3 for $12 \mathrm{c}$; $35 \mathrm{c}$ doz.; $\$ 2.50$ per 100 .

BARON HULOT (Lemoine) A beautiful dark violet, bordering on blue. A straight spike of well arranged flowers. $8 \mathrm{c}$ each; 3 for $20 \mathrm{c} ; 75 \mathrm{c} \mathrm{doz} ; \$ 6$ per 100.

BRENCHLEYENSIS (Youell) Vermillion scarlet. Not large-but much in demand on account of brilliant color. 3c ench; 3 for 8c; 25e doz; $\$ 1.75$ per 100.

MAY (Crawford) A charming white fincly flaked with bright crimson. $5 \mathrm{c}$ each, 3 for $12 \mathrm{c}, 40 \mathrm{c}$ doz. 